\title{
Educação em saúde na escola: promovendo a saúde por meio do lúdico, da linguagem artística e da literatura infantil
}

\author{
Ezequias Tenório da Silva, Allan Brasileiro Rocha, Fernanda Andrade da Silva
}

\begin{abstract}
Resumo
A escola como parte do processo educativo que permeia a vida das pessoas, se torna um cenário para compartilhar os conhecimentos e diferentes saberes sobre saúde. Compreendendo a saúde como fenômeno social, Matielo (2009) refere que a educação em saúde atua em uma perspectiva de potencializar ações que conduzem à autonomia, ao empoderamento e ao despertar da consciência crítica dos indivíduos. Como elemento direcionador desse trabalho tem-se a promoção da saúde que compreende o enfrentamento dos fatores sociais, econômicos, políticos e culturais, coletivos e individuais para favorecer a qualidade de vida. A UFPR Setor Litoral preocupada com a promoção da saúde no ambiente escolar e em torno dela propõe o projeto denominado "Promoção da saúde a partir do imaginário infantil" integrante do programa de extensão "Mundo Mágico da Leitura". Com início em 2012, busca conhecer a realidade da comunidade local, promovendo espaços de atuação interdisciplinar com a participação de discentes dos cursos Saúde Coletiva, Artes, Linguagem e Comunicação. Este trabalho conta com o apoio do lúdico no processo de aprendizagem, incluindo a linguagem artística e a literatura infantil. Como a saúde é um dos temas transversais apontado nos Parâmetros Curriculares Nacionais (PCN's) aborda-se com o intuito da comunidade agir com responsabilidade em relação à saúde individual e coletiva. O projeto tem como objetivo estimular a discussão sobre a saúde ancorada na Promoção da Saúde e em práticas educacionais nos espaços escolares e comunitários articulando as compreensões de diferentes indivíduos provindos de diferentes contextos sociais e culturais. A metodologia do projeto aborda a pedagogia Histórico-Crítica de Gasparin (2003), o modelo pedagógico de Paulo Freire e as estratégias de leitura de Isabel Solé (1993). Para o ano de 2016, as ações estão sendo realizadas em um Centro Municipal de Educação Infantil, uma Escola Municipal e em uma Escola Estadual localizadas no município de Matinhos-PR. Verificaram-se as temáticas a partir de uma avaliação diagnóstica com a equipe diretiva e pedagógica, além da participação de professores e estudantes, podendo citar sexualidade, meio ambiente, higiene, drogas, violência doméstica, respeito e alimentação saudável. E no decorrer realizam-se as avaliações somativa e formativa. Desenvolve-se o trabalho quinzenalmente nas instituições parceiras para 470 educandos, respectivamente 125 adolescentes e 345 crianças, público que possui entre 2 e 16 anos de idade. As estratégias utilizadas englobam a contação de histórias, jogos teatrais e as discussões temáticas que possibilitam o desenvolvimento da expressão e a interpretação para a tomada de atitudes mais saudáveis e conscientes. Nas observações in loco durante as ações do projeto, verificou-se que as crianças aguardavam ansiosamente pelas atividades desenvolvidas, os resultados demonstram que no desenvolvimento das atividades pode-se observar a interação dos estudantes com o grupo e há a compreensão dos temas. Dessa forma, visualiza-se que os cuidados em saúde estão vinculados às experiências e que ao realizar as práticas educativas de maneira dialógica, dinâmica e problematizadora oportuniza-se as transformações que fazem sentido para a vida.
\end{abstract}

Descritores: Educação em saúde; promoção da saúde; lúdico. 